\title{
TAXATION OF REFUNDED AMOUNTS DEDUCTED IN PRIOR YEARS: CHARITABLE CONTRIBUTIONS
}

THE ouestron whether the recovery of prior losses or payments
previously deducted should be reported as income in the year of recovery
or should be related to the previously reported deduction has a history
studded with conflict. The resolution of this problem depends upon
whether the principle of "annualization"2 of the taxable year is to be
modified by a "transactional"3 approach of reporting the repayment of
erroneously received income or erroneously taken deductions. The
Court of Claims recently made another" attempt to mitigate the rigors"

\footnotetext{
1 "The question of whether a recovery is properly accounted for as income in the year received or should be related to a previous reported deduction without tax benefit is one with a long history and much conflict. It arises not only in case of recoveries of previously charged off bad debts and recoveries of the type we have here. It is also present in case of refund of taxes or cancellation of expenses or interest previously reported as accrued, adjustments of depreciation and depletion or amortization, and other similar situations." Dobson v. Commissioner, 320 U.S. 489 , n. 36 ( (1943).

2 "Annualization" of the taxable year refers to the reporting as income of all amounts received by the taxpayer during his annual accounting period. "Taxable income must be computed on the basis of the taxpayer's taxable year. The term 'taxable year' means the annual accounting period on the basis of which the taxpayer regularly computes his income in keeping his books, if it is either (I) a calendar year or a fiscal year, or (2) the period for which the return is made, if made for a period of less than I2 months." 3 CCH I958 STAND. FEd. TAX REP. I 2715.01. See Burnet v. Sanford \& Brooks Co., 282 U.S. 359 (1932).

"The "transactional" approach toward reporting income for tax purposes recognizes that income must be reported on an annual basis but insists that the claim of right doctrine which fortifies the "annualization" concept be limited to ascertaining the accounting year in which the income is to be reported. Thus, prepaid amounts would be reported as income in the year of charge rather than the year of receipt. The "transactional" approach would allow tax accounting to report income on the basis of good commercial accounting practices by recognizing the fact that some commercial transactions may extend over a period of several years while the payment connected therewith may be received in one year. See Heffern, Claim-of-Right and Other Tax Doctrines Are Distorting Proper Accounting, 5 J. Taxation 20 (1956).

'For an example of a prior attempt, see United States v. Lewis, 340 U.S. 590 (1951); Note, 39 CALIF. L. REv. 447, 448 (1951).

${ }^{5}$ For example the claim of right doctrine, based on the annualization theory, refused adjustment to the year of receipt if in a subsequent period the taxpayer is required to restore claim of right income. In such cases it is self-evident that the taxpayer's economic position will be changed as a result of the tax procedures if his tax bracket has changed or the rate of tax has changed, or when deductions taken over a period of years are restored in one year. United States v. Lewis, 340 U.S. '590 (I95I); Perry v. United
} 
of the annualization theory under which each taxable year is considered a separate and closed entity for income tax purposes.

In Perry v. United States ${ }^{6}$ the taxpayers had created a charitable trust and in previous years had taken deductions for the contributions. Because of a contingency in the original trust agreement, the corpus of the fund was returned unused. ${ }^{7}$ The Commissioner ruled that this repayment must be included as income in the year of the return. The Court of Claims, however, merely required the taxpayers to increase their tax for the year of repayment to the extent their taxes had been decreased as the result of the previous charitable deductions. ${ }^{8}$

This decision has an obvious equitable appeal ${ }^{9}$ in that the actual economic position of the taxpayers was not changed: the tax benefits received by the taxpayers in earlier years were expunged, the accumulation of interest and dividends on the returned amount admittedly was taxable as income, and the appreciated value of the stock presumably can

States, 160 F. Supp. 270 (Ct. Cl, 1958); Heffern, supra note 3 ; Note, 49 Mich. L. REV. 1251 (1951).

160 F. Supp. 270 (Ct. Cl., 1958).

T The taxpayers conveyed stock in trust to be used to finance an addition to a public library. It was decided not to build the addition and the stock was returned to the taxpayers. In this action the taxpayers sought to recover income taxes in excess of $\$ 3000$ paid by them in 1953 covering an amount returned to them by the charitable trust to which they had made contributions in $1944-1948$, and for which they had taken charitable deductions.

${ }^{8}$ The decision of the court was by a 3-2 majority, the dissent arguing that the repayment should be taxed as income since it was neither a return of capital nor a gift back to the taxpayer.

${ }^{\circ}$ It is, however, often argued that a transactional approach would be inequitable because it interferes with the administration of the tax statutes. "A rule which required that the adjustment be made in the earlier year of receipt instead of the later year of repayinent would generally be unfavorable to taxpayers, for the statute of limitations would. frequently bar any adjustment of the tax liability for the earlier year. Congress has enacted an annual accounting system under which income is counted up at the end of each year. It would be disruptive of an orderly collection of the revenue to rule that the accounting must be done over again to reflect events occurring after the year for which the accounting is made, and would violate the spirit of the annual accounting system. This basic principle cannot be changed simply because it is of advantage to a taxpayer or to the Government in a particular case that a different rule be followed." Healy v. Commissioner. 345 U.S. 278, 284 (1953). "This conclusion without question results in a 'facilitation of the administration of the taxing statute,' for all tax returns for a particular year are thereby limited to the facts of that year regardless of later developments showing such facts to be erroneous for one reason or another. Any other result would force a reopening of the prior year for refund purposes, with obvious admimistrative difficulties attendant upon such a process." Webster, The Claim of Right Doctrine: 1954 Version, 10 TAX L. REv. 381, 382 (1955). See Note, 39 Calif. L. Rev. 447 (195I). 
be taxed at the time of final disposition by retaining the original cost as the basis. ${ }^{10}$ On legal grounds, however, the decision may be questioned, first, because it is not supported by earlier decisions ${ }^{11}$ and, second, because the court arrived at the decision illogically. Throughout its opinion the court gave lip service to, and even argued in support of, the principle of annualization, yet in the end it related the repayment back to the years of the deductions, a result totally inconsistent with the principle which the court purported to follow.

The original position of the United States Supreme Court in cases of recovery of losses or payments previously deducted was that any payment received during a taxable year was to be treated as income in that year, regardless of whether a tax benefit had been previously realized by the taxpayer. ${ }^{12}$ This concept of annualization of the invulnerable tax year, based on the statutory direction that "taxable income shall be computed on the basis of the taxpayer's taxable year, ${ }^{\prime 13}$ should have controlled the Perry case unless that case falls within some exception to the general rule which Congress has provided. ${ }^{\mathbf{1 4}}$

One such exception, ${ }^{15}$ reflecting more equitably the actual economic

\footnotetext{
${ }^{10}$ Since original cost was retained as basis for the stock, any appreciation in value will be taxed at the time of final disposition, and if the taxpayers choose not to sell the stock the Government is in no worse position than it would have been had the taxpayers held the stock continuously. If the basis had been as of the date of contribution to the charitable trust, the Government would have lost a tax on any increase in value over original cost when the stock is finally disposed of, and if the basis of the stock had been the value in 1953 (the date of return to the taxpayers), the taxpayers would have avoided at final disposition any tax upon the appreciation from original acquisition to 1953.

${ }_{11}^{11}$ See 4 P-H $195^{8}$ FEd. TAX SERv. T 32237.

12 "If a taxpayer receives earnings under a claim of right and without restriction as to its disposition, he has received income which he is required to return, even though it nay still be claimed that he is not entitled to retain the inoney, and even though he may still be adjudged liable to restore its equivalent." North American Oil Consol. v. Burnet, 286 U.S. 4I 7, 424 ( 1932 ); see United States v. Lewis, 340 U.S. 590 (x95I); Comment, 46 Ill. L. REv. 497 (1951); Note, 9 VAND. L. REv. 404 (I956).

${ }^{13}$ INT. REv. CODE OF I $954, \S 44$ I.

${ }^{14}$ See Note, 29 Texas L. REv. 966, 968 (1951).

${ }^{25}$ For other exceptions to the annualization principle see: Arrowsmith v. Commissioner, 344 U.S. 6 (1952); INT. REv. CODE OF 1954, $\S \S$ 172 (b), 382 (net operating loss carrybacks and carryovers), $\S 12 x_{2}$ (capital loss carryover), $\S 1301$ (compensation from an employment), $\S_{1302}$ (income from an invention or artistic work), $\S_{1303}$ (income from back pay), $\S_{304}$ (compensatory damages for patent infringement), $\S$ III (recovery of bad debts, prior taxes, and delinquency amounts), § 64 I I (tentative carryback adjustments), $\S_{3} 81$ (carryovers in certain corporate acquisitions), $\$ 270$ (limitations on deductions allowable to individuals in certain cases), $\$ 65 \times 1$ (limitations on credit or refund).
} 
results of whole transactions, is embodied in section III of the 1954 Code. ${ }^{18}$ That section allows the exclusion from gross income of all amounts realized by recovery of bad debts, prior taxes, or delinquency amounts which which did not result in tax benefits in a prior year. In the case of Dobson v. Commissioner ${ }^{17}$ the Supreme Court held that, although that section specifically mentioned only "bad debt, prior tax, or delinquency amount," the exclusion was also applicable to the recovery of a loss resulting from the prior sale of stock. Prompted by this decision, T.D. $5454^{18}$ extended the tax benefit rule to the recovery of virtually all losses, expenditures, and accruals. Thus, recoveries of previously deducted payments or losses of practically any type will be treated as income in the year in which they are received only if a tax benefit was realized as a result of the prior deduction. Since there had been a tax benefit in the Perry case, the decision cannot be supported by section II I or T.D. $5454^{19}$ The decision of the Court of Claims, therefore, must be supported, if at all, on some other basis.

\footnotetext{
${ }^{10}$ INT. REv. CODE OF 1954, § III replaced INT. REV. CODE OF 1939, § 22 (b) (12). $\S$ III(a) provides, "Gross income does not include income attributable to the recovery during the taxable year of a bad debt, prior tax, or delinquency amount, to the extent of the amount of the recovery exclusion [an amount which did not result in a reduction of the taxpayer's tax] with respect to such debt, tax, or amount." This rule is often called the tax benefit rule since only amounts which in prior years resulted in tax benefits are taxable.

${ }^{28} 320$ U.S. 489 (1943). See Tuttle v. United States, 101 F. Supp. 532, 535 (Ct. Cl. 1951).

${ }^{18}$ This decision by the Treasury in effect amended what is now INT. REv. CODE of I954 § III to cover all losses, expenditures, and accruals made the basis of deductions from gross income for prior taxable years except deductions for depreciation, depletion, amortization, or amortizable bond premiums. T.D. 5454, CuM. BuLl. 68 (1945). "A basic requirement in applying the tax benefit rule is the necessity for the existence of an inter-relationship between the event which constitutes the loss and the event which constitutes the recovery so that they can be considered as parts of one and the same transaction." I P-H I958 FED. TAX SERV. I 7391-A.

${ }^{10}$ The taxpayers obtained the benefit via tax deductions of the value of the securities at the time of the deductions. Thus, under the tax benefit rule, the income attributable to the return should be ineasured by the value of the securities at the time of deduction. Any excess value due to appreciation will be taxed at the time of final disposition. The taxpayers' position in the instant case is analogous to that of a person who has paid taxes or deducted a bad debt and later recovers the amount dedncted. "Occasionally a taxpayer will deduct on his return an item which he has paid to a third party under a mistaken belief that the third party has a claim of right to the item. In a later year he recovers the item previously deducted. Generally, the amount recovered will be taxed to him in full in the year of recovery." 4 CCH 1958 STAND. FED. TAX REP. I 4837 C. "Contributions to exempt organization, earmarked for particular purpose, was subsequently transferred at request of donor to a nonexempt fund; contribution was income to donor for year of transfer to extent of amount previously taken as deduc-
} 
Since the occurrence of the facts involved in the Perry case, Congress has provided another exception to the general rule of annualization, section 1342 of the Internal Revenue Code. ${ }^{20}$ That section allows a taxpayer the privilege ${ }^{21}$ of excluding from the income of the current taxable year the amount of the recoupment and adding to his tax the amount which had previously been saved by deducting the item, when such item was deducted in the prior year "... . because it appeared that another person had an unrestricted right to such item as a result of a court order in a patent infringement suit ... and ... it was established after the close of such prior taxable year (or years) that such other person did not have an unrestricted right to such item.".22 The legislative history ${ }^{23}$ of section 1342 suggests that it was intended to complement section $\times 34 \mathrm{r},{ }^{24}$ which deals in general with the taxation of amounts

tions." I P-H 1958 FED. TAX SERV. I 7411; see Western Products Company, 28 T.C. No. 143 (1957).

${ }^{20}$ INT. REv. CODE OF 1954, $\$ 1342$. This section "is limited to situations where an item was deducted from gross income for a prior taxable year . . . because it appeared that another person held an unrestricted right to such item as a result of a court decision in a patent infringement suit, which court decision was later reversed on the ground that such decision was induced by fraud or undue influence. Also, the recovered item must amount to $\$ 3,000$ or more." $4 \mathrm{CCH}$ I958 STAND. FED. TAX REP. T 4837 C.or.

${ }^{21}$ INT. REv. CODE OF $1954 \$ 1342$ gives the taxpayer alternatives "in such cases to exclude the recovered item from the income of the recovery year and instead add to the tax of the recovery year an amount represented by the difference between the tax paid in the prior year of deduction and the tax that would have been paid had the deduction not been taken. If the $\operatorname{tax}$ so computed is less than the tax which would be paid by including the recovery in gross income, that is the amount of tax to be paid for the recovery year. This alternative treatment is applicable to taxable years beginning after December 3I, 1954." 4 CCH 1958 STAND. FED. TAX REP. I 4837C.or.

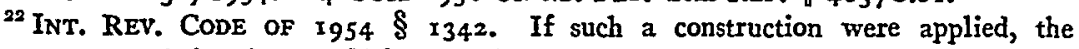
instant taxpayers' situation would be accorded the same treatment as that given taxpayers in patent infringement suits. Thus, all taxpayers with equal claims to equitable relief would be treated the same. Cf. Perry v. United States, r60 F. Supp. 270 (Ct. Cl. r958) (dissenting opinion).

${ }^{23}$ I 955 U.S. CODE CONG. \& AD. NEwS 3106.

26 "If an item was included in gross income for a prior taxable year . . . because it appeared that the taxpayer had an unrestricted right to such item; a deduction is allowable for the taxable year because it was established after the close of such prior taxable year ... that the taxpayer did not have an unrestricted right to such item or to a portion of such item; and the amount of such deduction exceeds $\$ 3,000$, then the tax imposed by this chapter for the taxable year shall be the lesser of the following: the tax for the taxable year computed with such deduction; or an amount equal to the $\operatorname{tax}$ for the taxable year computed without such deduction, minus the decrease in $\operatorname{tax}$ ... for the prior taxable year ... which would result solely from the exclusion of such item . . f from gross income for such prior taxable year. . . ." INT. REV. CoDE OF 1954, $\S$ I34X(a); see I P-H I 958 FEd. TAX SERV. If 6585. 
previously held by a taxpayer under a claim of right but then surrendered. Therefore, the court today might assert that Congress' attention was directed only to the narrow situation arising from a patent infringement suit, when section I 342 was enacted, and that Congress would have included within the privilege of that section the recovery of all other items previously deducted if that broad question had been presented. Thus, under facts similar to those in the Perry case, by analogy to the liberal interpretation of section III, a court might reach the same result as in Perry.

This argument is weakened by the many cases in which it has been explicitly stated that the courts have no power to ameliorate any harsh or arbitrary tax formula which Congress may prescribe. ${ }^{25}$ Even the Dobson case was grounded in part on the theory that the Tax Court's determination was final, if found to have a reasonable basis in law and fact, and the apparently liberal construction of the tax statute in that case is not supported by other Supreme Court decisions. The Court's position usually is that, since the legislative branch and not the judiciary is the cause of any injustice in the Code, any ameliorating change must come from Congress. ${ }^{28}$ Thus, we may guess that the Supreme Court would not accept the argument of analogy to the Dobson case, but would hold that Congress, by extending legislative relief only to patent infringement cases, intended that all other deductions recovered should be treated as taxable income in the year of recovery. ${ }^{27}$

The formidable struggle continues between the annualization and the transactional theories. ${ }^{28}$ The lower federal courts have on many previous occasions tried to limit the rigors of the annualization doctrine only to have their decisions reversed. ${ }^{29}$ This evidence of steadfastness

${ }^{25}$ "The taxpayer points to the consequences of error and other difficulties confronting one who in good faith tries to choose the proper year in which to claim a deduction. But these difficulties are inherent under the statute as now framed. Any desired remedy for such a situation, of course, lies with Congress rather than with the courts. It is beyond the judicial power to distort facts or to disregard legislative intent in order to provide equitable relief in a particular situation." Boehm v. Commissioner, 326 U.S. 287, 295 (1945). See Denny L. Collins, 29 T.C. No. 75 (Jan. 20, 1958); Emilie Furnish Funk, 29 T.C. No. 32 (Nov. 20, 1957); N. Gordon Phillips, 29 T.C. No. 7 (Oct. 16, 1957).

${ }^{28}$ Comment, 46 ILI. L. REv. 497 (1951); Note, 39 CALIF. L. REv. 447 (1951); Note, 29 TEXAs L. REV. 966 (195x); see note 38 supra.

${ }^{27}$ Provided, of course, that a tax benefit was realized at the time of the deduction.

${ }^{28}$ See Burnet v. Sanford \& Brooks Co., 282 U.S. 359 (193 I); and Heiner v. Mellon, 304 U.S. $27 \times$ ( $\times 938)$, indicating the existence of this problem in the past.

${ }^{20}$ Webster, The Claim of Right Doctrine: 2954 Version, 10 TAX L. REv. 381 (x955); Note, 29 TEXAS L. REv. 966 (x95x). 
[Vol. 1959: 151

by the Supreme Court prompts the prediction that the Court will reverse the instant attempt to institute a transactional approach toward reporting income and that, in doing so, it will give renewed vigor to the concept of the annual taxable year. 